\title{
HELLO PARENTS APPLICATIONS: DEVELOPMENT OF WEB-BASED SCHOOL ADMINISTRATION SYSTEM
}

\author{
Ninda Dwi Astuti \\ Universitas Muhammadiyah Surakarta, Jawa Tengah, Indonesia \\ Email: nindadwiastuti12@gmail.com \\ Chandra Gupta N.K.S \\ Universitas Muhammadiyah Surakarta, Jawa Tengah, Indonesia \\ Email: chandraagupta4@gmail.com \\ Febri Setiani \\ Universitas Muhammadiyah Surakarta, Jawa Tengah, Indonesia \\ Email: febrisetiani@yahoo.com
}

DOI: 10.35445/alishlah.v12i1.173

Accepted: January $5^{\text {th }}, 2020$. Approved: June $28^{\text {th }}, 2020$.

Published: June $30^{\text {th }}, 2020$

\begin{abstract}
The development of technology is currently developing very rapidly. This needs to be utilized in education, especially school agencies. Because currently there are many school activities that need to be developed so that the school system can develop for the better. The purpose of this study is to (1) facilitate the school administration system (2) make it easier for parents to see student's academic development (3) create innovation in the school administration system. The method used in this study uses a qualitative approach and is developed with the waterfall model. The results of this study are the application design "Hello Parents" which is an application development system administration in webbased schools. This application contains big data in the form of school information, teacher information, student report cards, payments, school agenda, and student academic development.
\end{abstract}

Keywords: Application, Administration, Hello Parents, Web 
Al-Ishlah: Jurnal Pendidikan - ISSN: 2087-9490 (p); 2597-940X (e)

Vol. 12, No. 1 (2020)

\title{
APLIKASI HELLO PARENTS: PENGEMBANGAN SISTEM ADMINISTRASI SEKOLAH BERBASIS WEB
}

\begin{abstract}
Abstrak
Perkembangan teknologi saat ini berkembang sangat pesat. Hal ini perlu dimanfaatkan dalam pendidikan khususnya instansi sekolah. Karena saat ini banyak kegiatan sekolah yang perlu dikembangan agar sistem sekolah dapat berkembang menjadi lebih baik. Tujuan dari penelitian ini untuk (1) mempermudah sistem administrasi sekolah (2) mempermudah orang tua dalam melihat perkembangan akademik siswa (3) menciptakan inovasi dalam sistem administrsi sekolah. Metode yang digunakan dalam penelitian ini menggunakan pendekatan kualitatif dan dikembangkan dengan model waterfall. Hasil penelitian ini adalah rancangan aplikasi "Hello Parents" yang merupakan aplikasi pengembangan sistem administrasi di sekolah berbasis web. Aplikasi ini berisi big data berupa informasi sekolah, informasi guru, raport siswa, pembayaran, agenda sekolah, serta perkembangan akademik siswa.
\end{abstract}

Kata Kunci: Aplikasi, Administrasi, Hello Parents, Web

\section{PENDAHULUAN}

Perkembangan kemajuan teknologi yang sangat pesat menjadikan hampir semua kegiatan sehari-hari tidak lepas dari teknologi. Perkembangan teknologi yang terjadi saat ini dapat dimanfaatkan dalam berbagai bidang, salah satunya di bidang pendidikan. Dunia pendidikan di Indonesia telah masuk ke era pendidikan 4.0, yang mengimplementasikan internet ke semua kegiatan pendidikan. Pendidikan khususnya instansi sekolah bisa memanfaatkan teknologi dalam sistem administrasinya. Dalam sistem administrasi sekolah berupa sarana dan prasarana, kurikulum, pembayaran, personalia dan administrasi siswa. Contohnya sistem pembayaran di sekolah saat ini masih banyak menggunakan rekapan manual dalam buku. Selain itu, nilai siswa yang saat ini juga masih menggunakan buku raport atau kertas dalam menyampaikan hasil belajar siswa. Permasalahan lain yaitu orang tua yang kurang waktunya untuk datang ke sekolah karena kesibukan pekerjaan. Sehingga banyak orang tua yang mewakilkan untuk mengambil raport anaknya yang mengakibatkan orang tua tidak bisa mengetahui perkembangan anak serta tidak bisa berkonsultasi secara langsung dengan guru. Jika perkembangan siswa tidak dapat diketahui secara langsung oleh orang tua akan mengakibatkan perkembangan siswa tidak bisa terpantau dengan baik. Melalui lembaga pendidikan yang menyediakan fasilitas informasi yang dapat 
Al-Ishlah: Jurnal Pendidikan - ISSN: 2087-949o (p); 2597-940X (e)

Vol. 12, No. 1 (2020)

menunjang kenyamanan dalam proses belajar mengajar sehingga dapat menghasilkan sumber daya manusia yang handal (Durachman, 2009).

Sistem Informasi Raport Online dirancang untuk mempermudah pekerjaan guru secara cepat tanpa membutuhkan waktu dan media penyimpanan yang banyak serta sulit untuk mencarinya, aplikasi ini mengelola nilai maupun memberikan informasi kepada orang tua (Budiarto, 2016). Dengan adanya suatu pengolahan dan manajemen yang baik, pengolahan data nilai akan lebih mudah, cepat, dan akurat. Dimana dengan adanya sistem, pengolahan yang selama ini dilakukan dengan manual dapat diatasi serta dapat membantu memperlancar proses pengolahan nilai siswa (Pangastuti, 2019). Sistem yang seperti itu dirasa kurang optimal, karena hanya memberikan hasil penilaian akhir dari semua aktivitas belajar siswa, sehingga proses-proses pembelajaran yang dilakukan oleh siswa setiap harinya tidak terpantau secara optimal (Anam, 2018).

Dalam membantu meningkatkan prestasi anak, peran orang tua sangat diperlukan. Dimana orang tua dapat mengetahui prestasi anak secara real time atau informasi mengenai perkembangan anak tersedia secara langsung sehingga orang tua dapat melakukan suatu upaya untuk membantu dalam meningkatkan prestasi anak (Yusuf, 2017). Maka dari beberapa kekurangan dalam administrasi sekolah tersebut harus ada inovasi yang dapat membantu guru dalam menyusun administrasi sekolah. Hal ini dapat diwujudkan dengan rancangan aplikasi yang memuat sistem adimistrasi tersebut. Aplikasi merupakan rancangan sistem dengan menggunakan bahasa pemrograman yang digunakan dalam mengolah data.. Aplikasi dibuat untuk mengerjakan dan melaksanakan tugas tertentu dari user dengan menggunakan komputer berbasis pemrograman. (Rosa, A.S dalam Yusuf, 2017).

Orang tua serta guru diharapkan mampu bekerja sama untuk mengetahui perkembangan anak. Orang tua dapat menjadi pendidik saat anak berada di rumah. Pendidikan keorangtuaan atau parenting merupakan hal yang sangat penting. Dalam hal ini orang tua perlu dilibatkan sebagai pendidik atau mitra kerja dalam lingkungan sekolah yang dilakukan di rumah dengan cara memberikan program pendidikan keorangtuaan agar mampu menjalankan tugasnya sebagai seorang pendidik. Pendidikan yang diajarkan di rumah dapat sejalan dengan pendidikan di sekolah merupakan hal yang sangat penting yaitu kerjasama antara wali murid dan sekolah (Lindasari, 2017).

Program akademik dievaluasi dan dinilai untuk mengontrol kualitas dan peningkatan penawaran program. Proses evaluasi melibatkan penilaian serangkaian hasil belajar yang menunjukkan apa yang lulusan bisa dan mampu dilakukan setelah lulus. Berbagai macam alat ada untuk menilai sejauh mana hasil belajar terpenuhi, seperti responden, peringkat siswa, nilai ujian, dan hasil belajar siswa (Abdullah, 2019). Program di sekolah dapat dikembangkan menjadi sistem 
Al-Ishlah: Jurnal Pendidikan - ISSN: 2087-949o (p); 2597-940X (e)

Vol. 12, No. 1 (2020)

yang kinerjanya menggunakan perangkat komputer, salah satunya adalah program sistem informasi pembayaran. Perkembangan dan pemanfaatan teknologi informasi ini menjadi perhatian khusus di dunia pendidikan khususnya di sekolah. Hal ini dikarenakan dalam sistem pembayaran atau pengelolaan keuangan sekolah masih meggunakan cara manual yaitu dengan pencatatan di buku besar dan menggunakan kuitansi. Sehingga pada saat pelaporan keuangan harus merekap kuitansi dan membuka buku besar kembali (Heni, 2012).

Membangun sistem yang berbasis web merupakan salah satu cara untuk memudahkan pihak bendahara sekolah dalam mengontrol laporan pembayaran Sumbangan Pembinaan Pendidikan (SPP) sekolah agar dapat terpantau dengan baik dan memperkecil kesalahan data yang tidak tercatat dan mempercepat kinerja. Hal ini dibuat karena dalam sistem pembayaran guru sering mengulangulang dalam penyusunan rekap keuangan karena sering terjadi kesalahan dalam memasukkan data (Rochman, 2018).

Guru dapat menghasilkan informasi dan laporan yang lebih cepat, akurat, dan relevan dengan kebutuhan dengan merancang sebuah aplikasi pengolahan Nilai Siswa Berbasis WEB yang merupakan salah satu pengaplikasian sistem untuk mengolah nilai siswa berbasis komputer (Nandika, 2014). Sebuah laporan mengenai keaktifan siswa dapat dilakukan secara online yang berupa laporan nilai serta informasi siswa yang bersangkutan dengan berbasiskan web, sehingga membantu kecepatan dan kualitas dalam penyampaian informasi. Sistem informasi tersebut merupakan sistem informasi pengolahan data nilai siswa berbasis web (Wardani, 2013).

Selain itu jika penyampaikan hasil nilai siswa yang masih menggunakan raport atau kertas tersebut akan dapat menimbulkan kesalahan baik dari guru dalam menulis nilai ataupun dalam percetakannya. Oleh karena itu dibutuhkan sebuah solusi yang dapat mengoptimalkan kinerja dalam pengolahan nilai yaitu sistem informasi akademik berbasis web adalah kemudahan dalam cara mengaksesnya yaitu dengan cara mengakses lewat browser yang ada pada perangkat komputer atau perangkat telepon (Suryandani, 2017).

\section{METODE PENELITIAN}

Pendekatan yang digunakan dalam penelitian ini adalah pendekatan kualititatif. Data yang diperoleh kemudian dianalisis dengan cara reduksi data, memilih hal-hal yang pokok, dan memfokuskan pada hal-hal yang penting (Lindasari, 2017). Dalam penelitian ini metodologi yang digunakan yaitu pengembangan model waterfall. Pemodelan Waterfall merupakan metode pengembangan sistem yang sering digunakan oleh para pengembang sistem 
Al-Ishlah: Jurnal Pendidikan - ISSN: 2087-949o (p); 2597-940X (e)

Vol. 12, No. 1 (2020)

dengan tahap pengembangan sistem yang terstruktur (Harjanto, 2018). Metode dalam pemodelan waterfall ini memberikan pendekatan-pendekatan sistematis dan berurutan bagi pengembangan sistem informasi (Susanti, 2016).

Pada metodologi waterfall dalam penelitian ini, tahap yang pertama dilakukan adalah studi literatur. Studi literatur adalah suatu dasar teori yang digunakan sebagai sumber landasan yang dijadikan penunjang dan memperkuat pemahaman kepustakaan. Kemudian tahap selanjutnya analisis kebutuhan dilakukan identifikasi untuk mencari kebutuhan-kebutuhan pada aplikasi yang akan dikembangkan, yaitu dengan membuat gambaran umum aplikasi yang menjelaskan jalannya aplikasi secara umum. Mengidentifikasi peran serta apa saja yang dapat aktor lakukan didalam aplikasi yang dibuat. Selanjutnya dijabarkan kebutuhan fungsional dan non-fungsional. Pada kebutuhan fungsional akan di gambarkan pada use case dan dijelaskan pada use case scenario. Selanjutnya tahap ketiga adalah perancangan sistem merupakan tahapan yang dilakukan setelah tahap analisis kebutuhan dilakukan. Langkah ini bertujuan untuk merancang alur navigasi antar muka dari tiap halaman yang terdapat pada sistem yang akan dibangun. Tahap selanjutnya tahap implementasi. Tahap yang mengacu dari hasil perancangan yang telah dilakukan. Tahap selanjutnya pengujian dan analisis yang bertujuan untuk mengetahui apakah hasil dari implementasi sudah sesuai dengan analisis kebutuhan dan perancangan yang telah dilakukan sebelumnya. Tahap yang terakhir kesimpulan diambil berdasarkan hasil dari tahap pengujian dan analisis. Sedangkan saran diberikan untuk memperbaiki kesalahan dan melengkapi kekurangan dari penelitian ini sehingga dapat dijadikan pertimbangan dalam pengembangan selanjutnya (Prasetya, 2018).

\section{HASIL DAN PEMBAHASAN}

Dalam rancangan aplikasi ini menggunakan sistem website agar dapat diakses dimana saja dan kapan saja. Penggunaannya cukup mudah yaitu cukup terhubung ke internet. Memiliki sebuah website mempunyai arti penting bagi sekolah. Suatu sekolah atau instansi memiliki sebuah wadah untuk menginformasikan profil, potensi, kegiatan, dan berbagai keunggulan kepada masyarakat umum dengan memiliki media informasi yang berupa website (Membara, 2014). Perancangan adalah suatu bagian dari metodologi pengembangan pembangunan suatu perangkat lunak yang dilakukan setelah tahapan analisis yang dimaksudkan untuk memberikan gambaran secara terperinci (Syahbana, 2013). Rancangan aplikasi "Hello Parents" dibuat untuk mempermudah sistem administrasi di sekolah. Aplikasi ini dapat diakses oleh 
Al-Ishlah: Jurnal Pendidikan - ISSN: 2087-9490 (p); 2597-940X (e)

Vol. 12, No. 1 (2020)

admin atau pegawai tata usaha, guru atau wali kelas serta wali murid. Dimana ketiganya memiliki peran yang berbeda-beda dalam menjalankan aplikasi ini.

Suatu permasalahan yang muncul dalam pendidikan dan pembelajaran dapat menggunakan pemanfaatan Teknologi Informasi dan Komunikasi (TIK) di sekolah ditujukan untuk membantu mengatasi masalah-masalah yang muncul (Anwas, 2011). Program yang memiliki kejelasan dalam aksesnya akan menciptakan daya tarik untuk siswa. Hal ini di karenakan, siswa cenderung memilih yang sederhana dan banyak informasi di dalamnya. Orang tua dan siswa juga dapat berpatisipasi kapanpun, dan dimanapun, seperti di bus, di rumah, bahkan ketika sedang berbelanja karena aplikasi ini tersedia dalam versi telepon genggam (Huda, 2018).

Siswa dapat dengan mudah memperoleh informasi mengenai kegiatan akademik maupun raport nilai perkembangan siswa itu sendiri dapat memanfaatkan teknologi dan sistem informasi yang baik. Suatu Institusi pendidikan memiliki website atau sistem informasi berbasis website dapat membantu siswa dan wali murid untuk memperoleh informasi serta perkembangan siswa sehingga perkembangan akademis siswa dapat terpantau oleh wali murid (Yamalia, 2019). Sedangkan menurut (Saputra, 2017) pada umumnya dibutuhkan sebuah server dalam suatu sistem informasi akademik serta instalasi untuk setiap sistem yang ada disekolah. Rancangan sistem aplikasi yang dibuat dapat dijelaskan dalam bentuk gambar sebagai berikut.

Tabel 1 Output Sistem untuk Pengguna

\begin{tabular}{|c|c|c|c|}
\hline No. & Aktor & Peran & $\begin{array}{l}\text { Output yang } \\
\text { dibutuhkan }\end{array}$ \\
\hline 1. & $\begin{array}{c}\text { Admin / } \\
\text { Tata Usaha }\end{array}$ & $\begin{array}{l}\text { Berperan untuk mengelola } \\
\text { dan melakukan } \\
\text { pemeliharaan aplikasi secara } \\
\text { keseluruhan }\end{array}$ & $\begin{array}{l}\text { 1. Melakukan login } \\
\text { 2. Memasukkan data dari } \\
\text { kepala sekolah, guru, } \\
\text { wali kelas, data } \\
\text { tagihan Sumbangan } \\
\text { Pembinaan } \\
\text { Pendidikan (SPP) }\end{array}$ \\
\hline 2. & $\begin{array}{c}\text { Guru / Wali } \\
\text { Kelas }\end{array}$ & $\begin{array}{l}\text { Berperan ikut serta dalam } \\
\text { mengelola } \\
\text { menggunakan aplikasi }\end{array}$ & $\begin{array}{l}\text { 1. Melakukan login } \\
\text { 2. Melakukan edit data : } \\
\text { biodata diri, input } \\
\text { nilai, edit nilai dalam } \\
\text { raport siswa }\end{array}$ \\
\hline 3. & Wali Murid & menggunakan & $\begin{array}{l}\text { 1. Melakukan login } \\
\text { 2. Melihat nilai raport }\end{array}$ \\
\hline
\end{tabular}


Al-Ishlah: Jurnal Pendidikan - ISSN: 2087-9490 (p); 2597-940X (e)

Vol. 12, No. 1 (2020)

\begin{tabular}{ll}
\hline \hline & siswa, melihat biodata \\
guru, melihat tagihan \\
dan laporan \\
Sumbangan \\
Pembinaan \\
Pendidikan (SPP) \\
\hline
\end{tabular}

\section{Tampilan Awal}

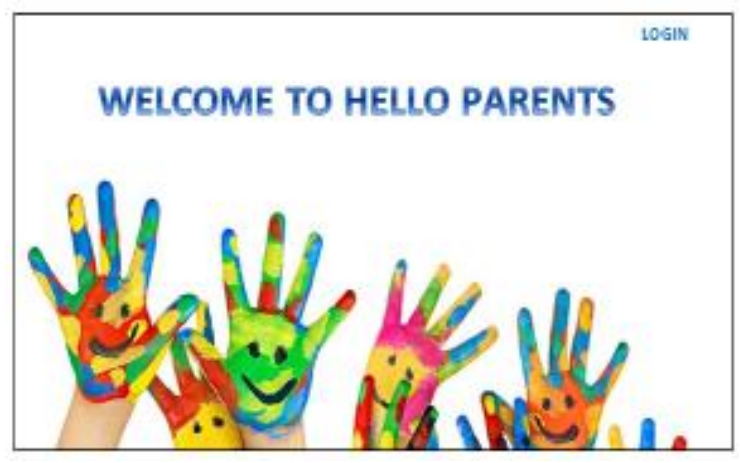

Gambar 1 Tampilan Awal Aplikasi

Jika masuk pada aplikasi Hello Parents maka tampilan awal akan muncul seperti gambar 1. Dalam tampilan awal pengguna dapat memilih login untuk masuk aplikasi.

\section{Tampilan Login}

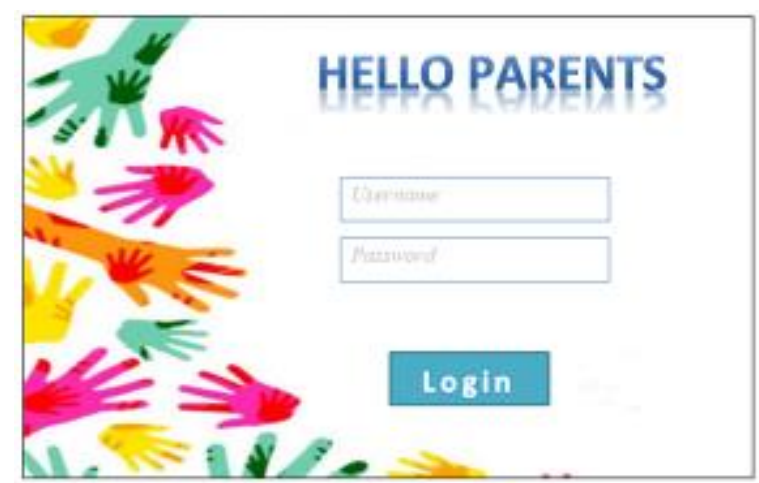

\section{Gambar 2 Tampilan Login}

a) Tampilan login untuk admin atau tata usaha, guru atau wali kelas dan wali murid siswa memiliki tampilan yang sama.

b) Username dan password untuk admin dibuat khusus yang hanya diketahui oleh pihak sekolah sedangkan untuk guru menggunakan nama 
Al-Ishlah: Jurnal Pendidikan - ISSN: 2087-9490 (p); 2597-940X (e)

Vol. 12, No. 1 (2020)

guru sebagai username dan password dapat menggunakan NIP atau dapat diganti oleh guru sendiri. Selanjutnya username dan password siswa menggunakan nama lengkap siswa dan nomor induk siswa (NIS).

\section{Tampilan Admin}

Admin atau administrator merupakan suatu pihak yang memiliki hak penuh untuk mengakses seluruh sistem. Administrator dapat melakukan input, melihat laporan dan mengedit data berupa: data kepala sekolah, data murid, data guru, data kelas, jurusan, mata pelajaran, dan ekstrakurikuler (Aristoteles, Aristoteles: 2013). Dalam aplikasi ini yang berwenang sebagai admin adalah pegawai TU (Tata Usaha). Dalam tampilan menu admin tedapat beberapa fitur yang terdiri dari.

a) Search, untuk mencari fitur.

b) Quick access, merupakan fitur yang diakses terakhir atau yang baru saja dibuka.

c) Profil sekolah, berisi informasi mengenai profil dari sekolah.

d) Manajemen data, berisi data wali kelas, data siswa, dan pembayaran atau tagihan.

e) Agenda, berisi mengenai kegiatan-kegiatan yang akan dilakukan sekolah, seperti rapat online.

f) Cetak, yaitu fitur jika orang tua ingin mencetak beberapa informasi dari aplikasi.

g) Pesan, digunakan untuk mengirim maupun menerima pesan.

h) Control panel, yang digunakan mengatur dan mengontrol menu dasar aplikasi, yang terdiri dari profil sekolah, agenda, siswa, pegawai, pengajar, dan kelas.

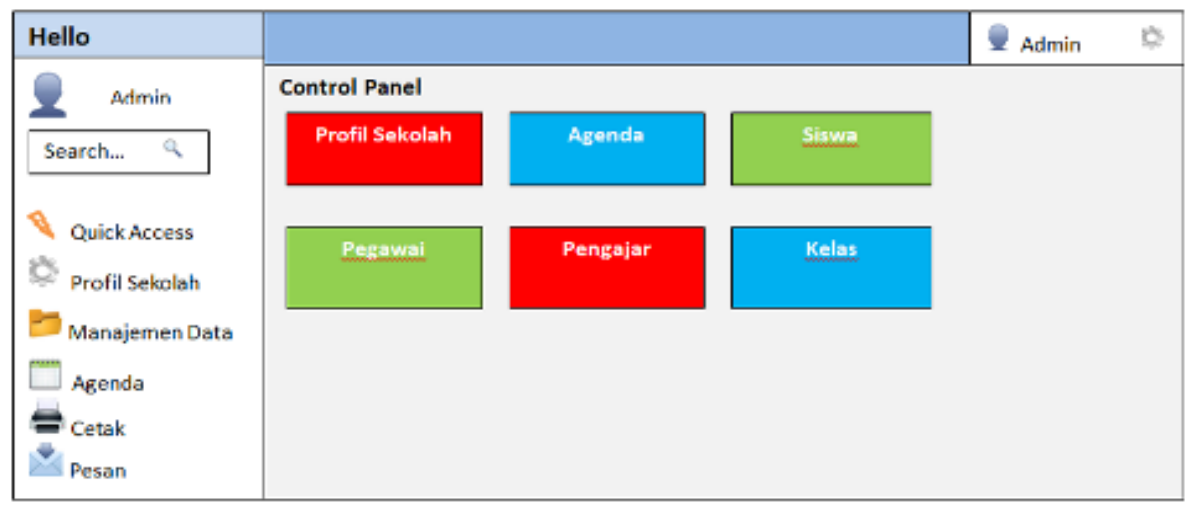

Gambar 3 Tampilan Admin 
Al-Ishlah: Jurnal Pendidikan - ISSN: 2087-949o (p); 2597-940X (e)

Vol. 12, No. 1 (2020)

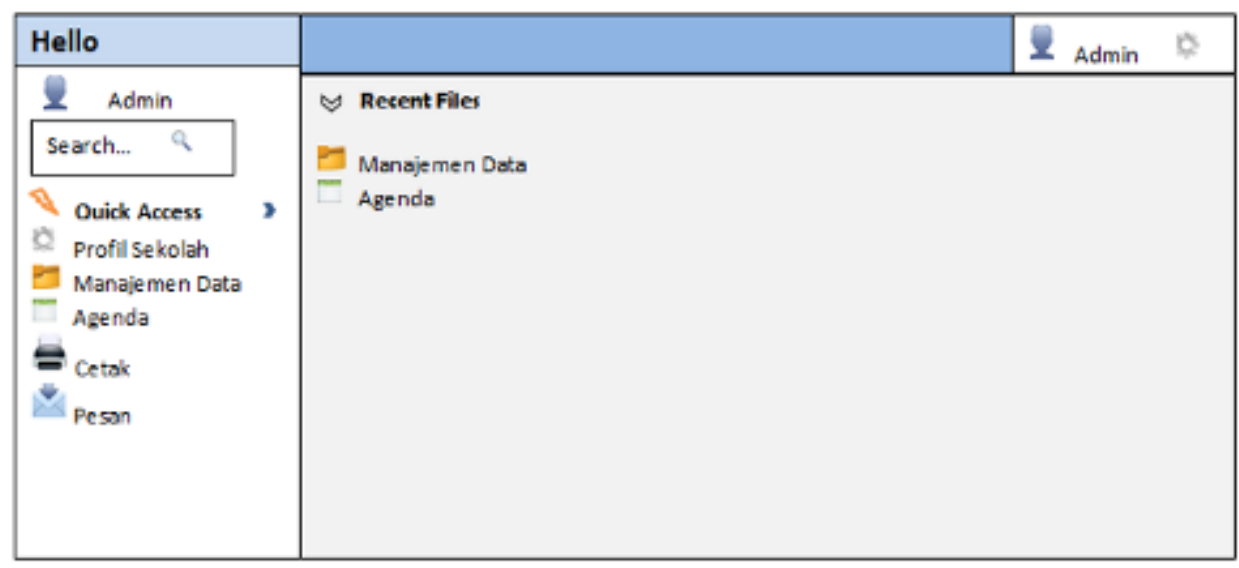

Gambar 4 Quick Access dalam Tampilan admin

Jika memilih pada ikon quick access maka akan muncul tampilan recent files. Recent files sendiri merupakan tampilan atau dokumen yang terakhir kali diakses atau dapat disebut sebagai histori.

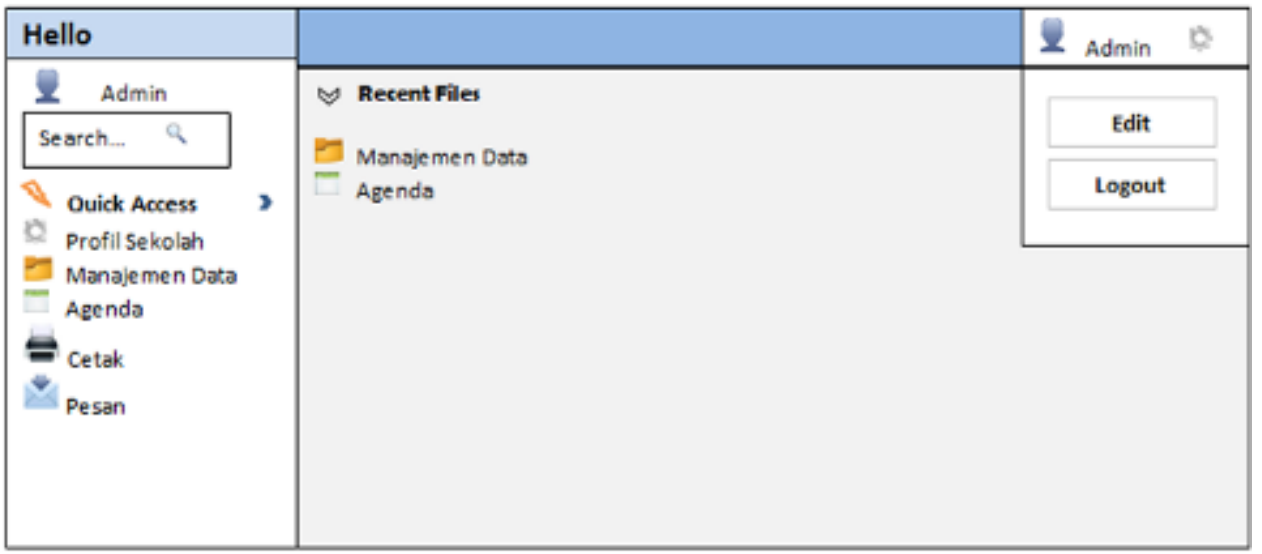

\section{Gambar 5 Ikon Pengaturan}

Jika memilih pada ikon pengaturan, muncul pilihan edit dan logout. Pilihan edit hanya akan muncul dalam menu admin dan guru. Pilihan edit dalam menu admin digunakan untuk mengisi atau merevisi data-data sekolah secara keseluruhan. Sedangan pilihan edit dalam menu guru hanya untuk menginput nilai siswa. Kemudian terdapat pilihan logout pada semua pengguna, untuk keluar dari aplikasi. 
Al-Ishlah: Jurnal Pendidikan - ISSN: 2087-9490 (p); 2597-940X (e)

Vol. 12, No. 1 (2020)

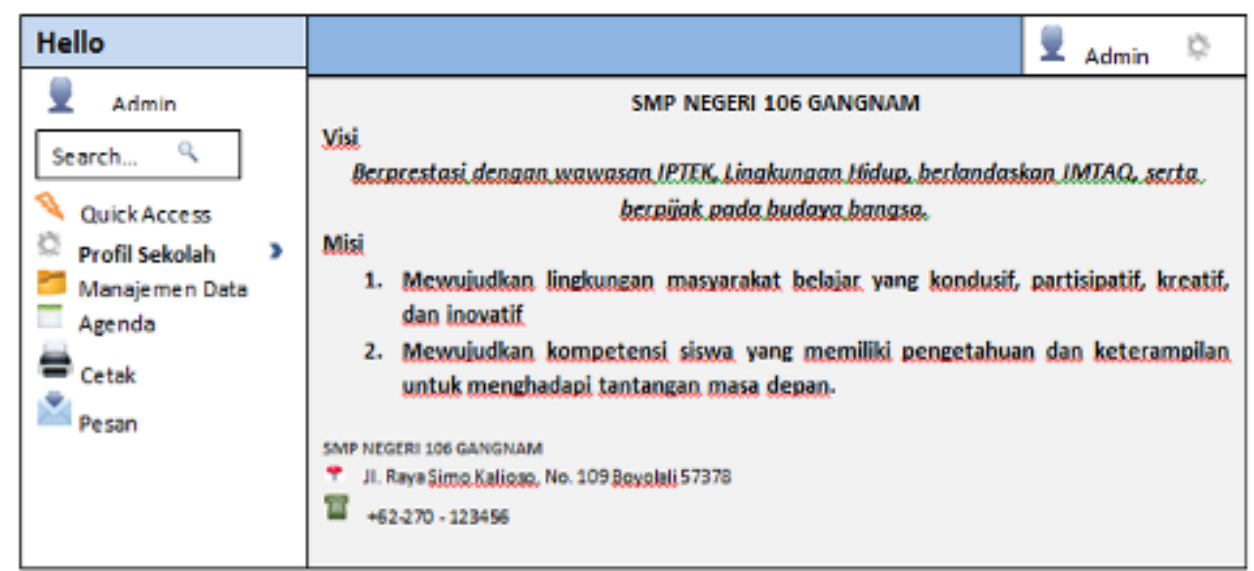

Gambar 6 Profil Sekolah dalam Tampilan Admin

Jika memilih ikon profil sekolah maka akan muncul tampilan yang berisi mengenai identitas sekolah. Pada tampilan yang muncul tersebut akan sama pada setiap penguna yang mengakses aplikasi Hello Parents yakni baik admin, guru, dan wali murid.

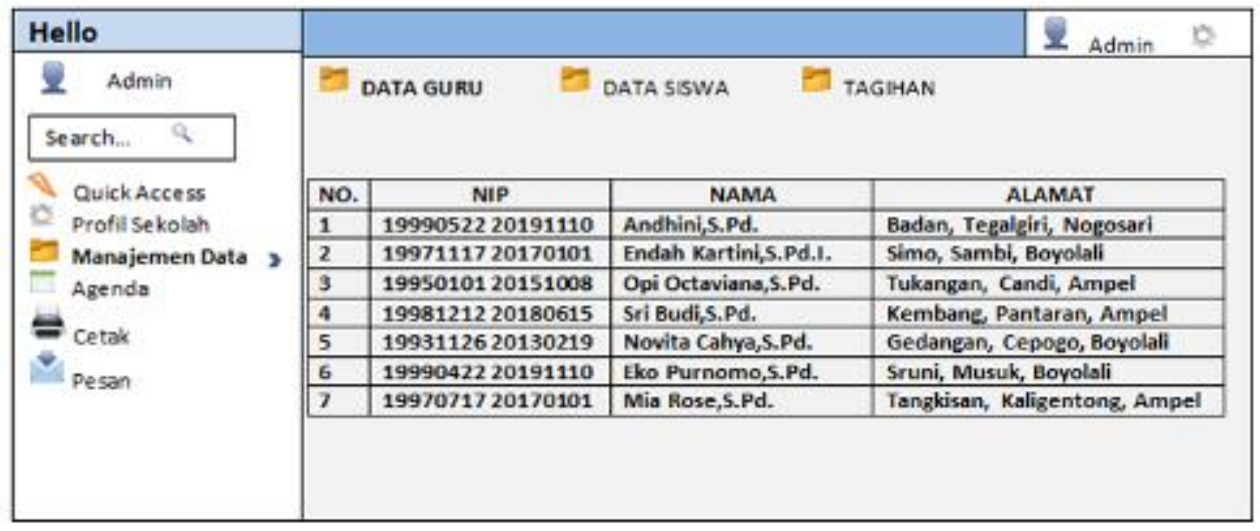

Gambar 7 Manajemen Data dalam Tampilan Admin

Jika memilih ikon manajemen data maka akan muncul tampilan yang berisi data administrasi sekolah seperti data guru, data siswa dan tagihan. Tampilan ini hanya terdapat pada akun milik admin yang dapat mengedit dan mengisi data yang ada. Pada pengguna yang lain yakni guru dan wali murid hanya dapat melihat data final yang diinput oleh admin. 
Al-Ishlah: Jurnal Pendidikan - ISSN: 2087-9490 (p); 2597-940X (e)

Vol. 12, No. 1 (2020)

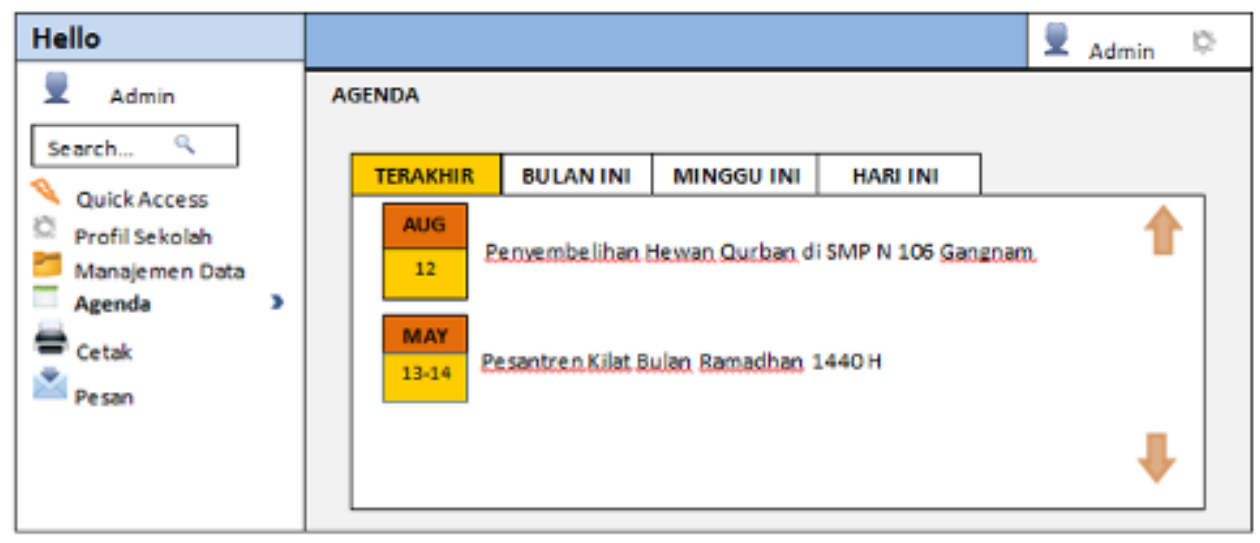

\section{Gambar 8 Ikon Agenda}

Jika memilih ikon agenda maka akan muncul tampilan agenda seperti gambar 8. Dalam agenda dibagi menjadi empat jenis yakni agenda terakhir, bulan ini, minggu ini, dan hari ini. Pada jenis agenda terakhir merupakan agenda yang sudah dilalui atau terakhir diadakan, dan untuk jenis yang lain sesuai dengan kondisi waktu yang tertera.

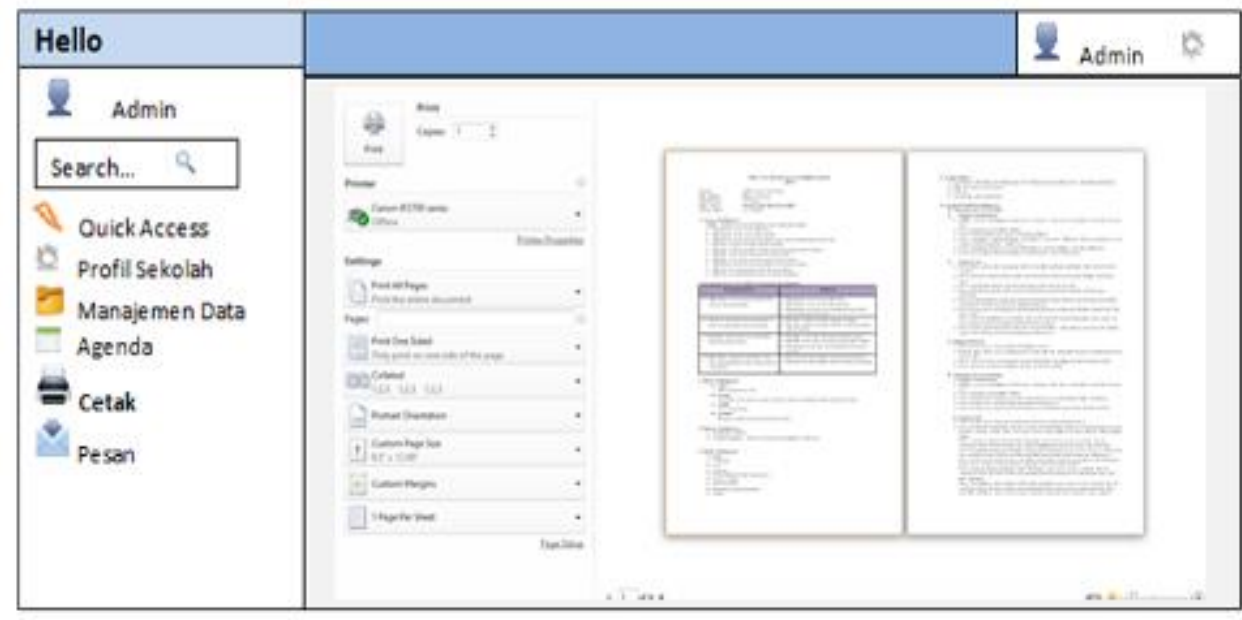

Gambar 9 Ikon Cetak

Jika memilih ikon cetak maka akan muncul tampilan untuk mencetak file yang diinginkan. Dimana didalamnya terdapat settings yang digunakan untuk mengatur jumlah halaman, jenis orientasi teks, margins, dan size kertas atau teks yang akan dicetak. Ikon atau fitur cetak ini digunakan apabila membutuhkan file untuk legalitas yang selanjutnya dapat dilegalisasi di bagian Tata Usaha sekolah. 
Al-Ishlah: Jurnal Pendidikan - ISSN: 2087-9490 (p); 2597-940X (e)

Vol. 12, No. 1 (2020)

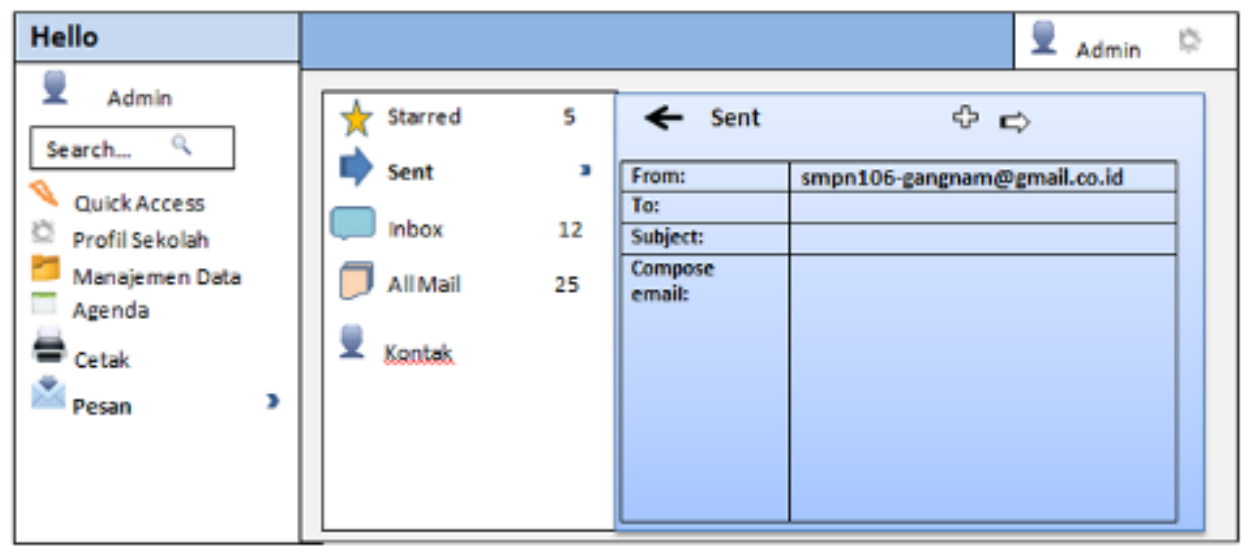

Gambar 10 Ikon Pesan

Jika memilih ikon pesan maka akan muncul tampilan seperti gambar 3.8, dalam tampilan pesan ini terdapat menu starred berfungsi untuk menemukan file yang dianggap penting sehingga mudah ditemukan, sent berfungsi untuk mengirim pesan, inbox merupakan pesan masuk, all mail merupakan semua $e$-mail yang masuk, dan kontak merupakan menu yang berisi kontak yang disimpan.

\section{Tampilan Guru}

Guru dalam aplikasi ini berperan ikut serta dalam mengelola aplikasi. Halhal yang dapat dilakukan guru yakni masuk pada akun (login), mengedit data berupa: biodata pribadi, memasukkan nilai, serta mengedit nilai siswa. Dalam tampilan guru, terdapat beberapa fitur diantaranya.

a) Search, digunakan untuk mencari fitur

b) Quick access, merupakan fitur yang diakses terakhir atau yang baru saja dibuka.

c) Profil, yang berisi biodata guru atau wali kelas.

d) Raport siswa, berisi nilai siswa dalam kelas yang diampu guru.

e) Perkembangan studi, berisi perkembangan masing-masing siswa dalam kelas yang diampu guru tersebut. Dapat digunakan juga untuk berkomunikasi dengan wali murid mengenai perkembangan studi siswa.

f) Agenda, berisi mengenai kegiatan-kegiatan yang akan dilakukan sekolah.

g) Cetak, yaitu fitur jika orang tua ingin mencetak beberapa informasi dari aplikasi.

h) Pesan, digunakan untuk mengirim maupun menerima pesan. 
Al-Ishlah: Jurnal Pendidikan - ISSN: 2087-949o (p); 2597-940X (e)

Vol. 12, No. 1 (2020)

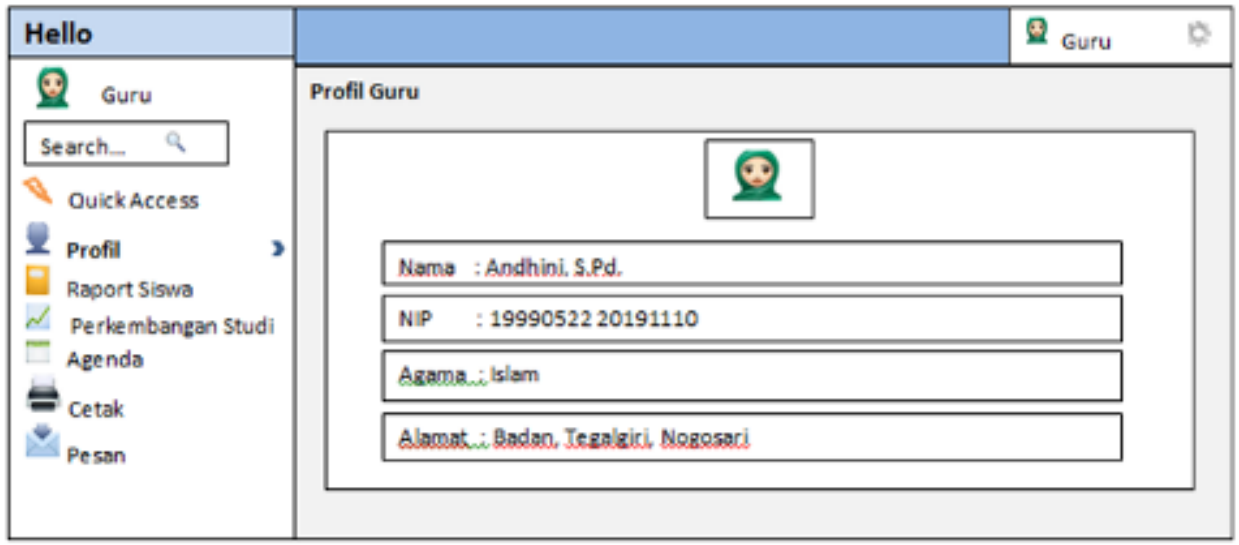

Gambar 11 Tampilan Profil Guru

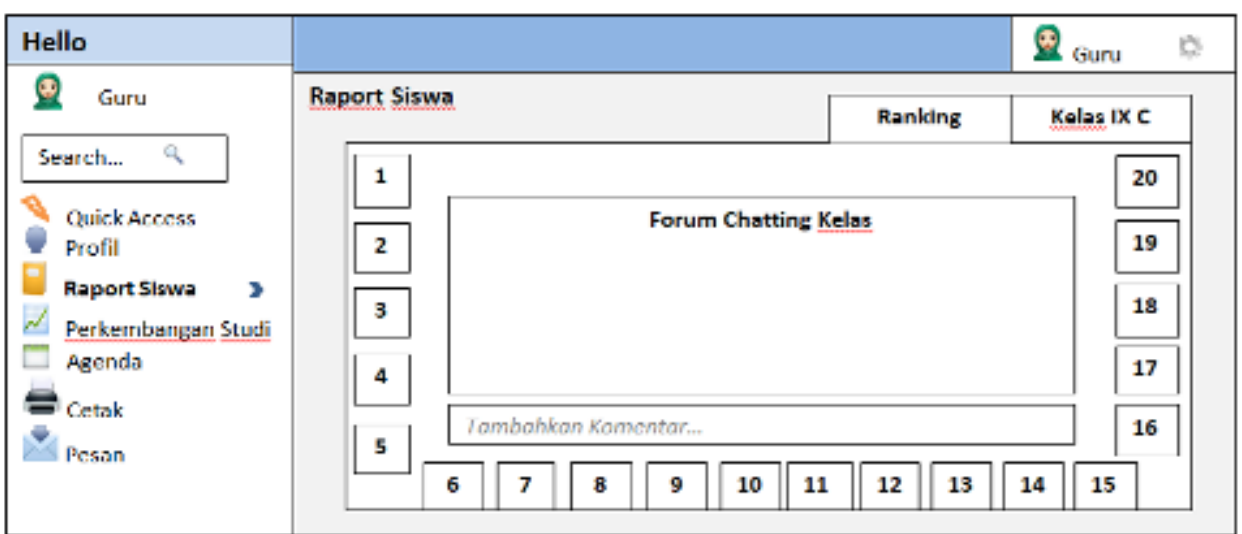

Gambar 12 Raport Siswa dalam Tampilan Guru

Dalam fitur raport siswa terdapat beberapa komponen diantaranya,

a) Data nilai siswa yang diampu guru, dapat dilihat ketika guru meng-klik pada nomor presensi siswa.

b) Ranking siswa, berisi peringkat 10 besar di kelas.

c) Forum chatting kelas, forum ini digunakan untuk memberikan informasi kepada seluruh wali murid di kelas yang diampu oleh guru. 
Al-Ishlah: Jurnal Pendidikan - ISSN: 2087-9490 (p); 2597-940X (e)

Vol. 12, No. 1 (2020)

\begin{tabular}{|c|c|c|c|c|c|c|}
\hline Hello & & & & & \multicolumn{2}{|l|}{ 요 Guru } \\
\hline Q2. Guru & \multicolumn{6}{|l|}{ Raport Siswa } \\
\hline Search... Q & \multirow{8}{*}{$\begin{array}{l}10 . \\
\text { Nama: } \\
\text { Jeni Rubic } \\
\text { NIS: } \\
20040315109\end{array}$} & NO & MATA PELAJARAN & PENGETAHUAN & PRAKTIK & KKM \\
\hline \multirow{7}{*}{$\begin{array}{l}\text { Quick. Access } \\
\text { Profil } \\
\text { Raport Siswa } \\
\text { Perkembangan Studi } \\
\text { Agenda } \\
\text { - Cetak } \\
\text { Pesan }\end{array}$} & & 1. & $\begin{array}{l}\text { Pendidikan Agama } \\
\text { Islam }\end{array}$ & 8,60 & 8,00 & 8,00 \\
\hline & & 2. & Bahasa Indonesia & 9,00 & 8,60 & 8,00 \\
\hline & & 3. & \begin{tabular}{|l|} 
Pkn \\
\end{tabular} & 8,00 & - & 8,00 \\
\hline & & 4. & Matematika & $\mid s i^{i}$ & $\mid i s i$ & 8,00 \\
\hline & & 5. & $\begin{array}{l}\text { Ilmu Pengetahuan } \\
\text { Alam } \\
\end{array}$ & $1 \mathrm{si}$ & isi & 8,00 \\
\hline & & 6. & $\begin{array}{l}\text { Ilmu pengetahuan } \\
\text { Sosial } \\
\end{array}$ & Isi & $i s i$ & 8,00 \\
\hline & & 7. & Bahasa Inggris & $\mid I S T$ & $\mid 15 I^{1}$ & 8,00 \\
\hline
\end{tabular}

Gambar 13 Input Nilai Siswa dalam Tampilan Guru

Guru dalam menginput nilai siswa meng-klik nomor presensi dan akan muncul tampilan seperti di atas. Guru hanya perlu memasukkan nilai berdasarkan mata pelajaran yang telah tertera dalam tampilan dengan meng-klik isi dalam kolom nilai.

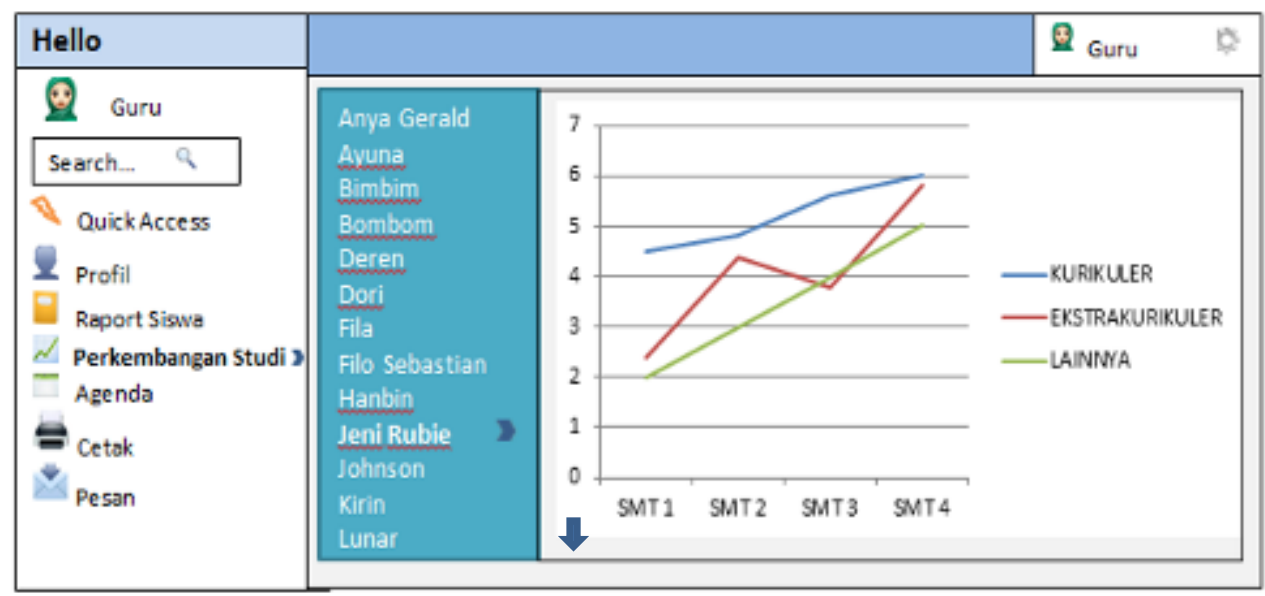

Gambar 14 Perkembangan Studi

Jika memilih ikon perkembangan studi maka akan muncul nama siswa yang diampu guru. Perkembangan studi ini berisi grafik perkembangan siswa yang terdiri dari nilai kurikuler, ekstrakurikuler, dan penilaian lainnya, dimana grafik akan muncul setelah diolah kedalam Ms. Excel yang telah diolah oleh admin.

\section{Tampilan Siswa}

Dalam tampilan menu siswa digunakan oleh wali murid yang berperan sebagai pengguna aplikasi. Wali murid perlu melakukan login. Dalam tampilan ini 
Al-Ishlah: Jurnal Pendidikan - ISSN: 2087-949o (p); 2597-940X (e)

Vol. 12, No. 1 (2020)

wali murid dapat melihat nilai raport siswa, melihat biodata guru, melihat Tagihan dan Laporan Sumbangan Pembinaan Pendidikan (SPP).

Dalam tampilan siswa, terdapat beberapa fitur diantaranya.

a) Search, digunakan untuk mencari fitur.

b) Profil, berisi informasi mengenai data diri siswa.

c) Perkembangan Studi, berisi mengenai evaluasi belajar siswa dan juga berisi konsultasi mengenai perkembangan akademik siswa kepada wali kelas.

d) Tagihan SPP, berisi beban tagihan sumbangan pembinaan pendidikan (SPP) yang harus dibayar wali murid.

e) Agenda, berisi informasi sekolah dan forum rapat online.

f) Cetak, digunakan untuk mencetak hasil belajar siswa atau informasi penting lainnya.

g) Pesan, digunakan untuk mengirim maupun menerima pesan.

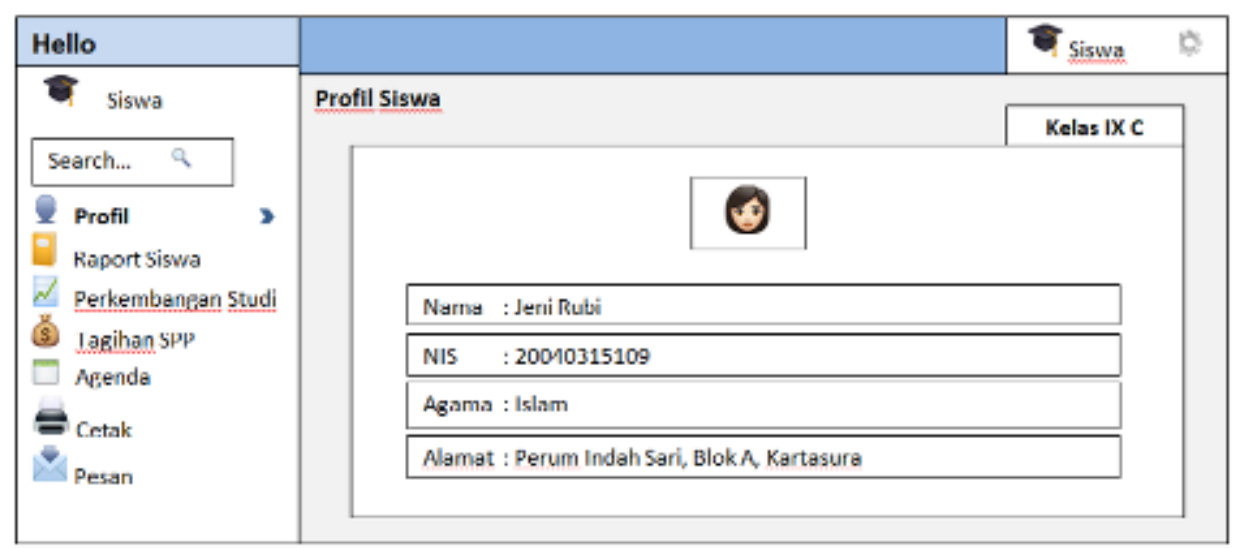

Gambar 15 Tampilan Profil Siswa

\begin{tabular}{|c|c|c|c|c|c|c|}
\hline Hello & & & & & \multicolumn{2}{|l|}{ * sisva } \\
\hline Sigva & Bilih Semester $\circlearrowleft$ & NO & MATA PELAJARAN & PENGETAHUAN & PRAKTIK & KKM \\
\hline Search___ Q & SMT 1/GASAL & 1. & $\begin{array}{l}\text { Pendidikan Agama } \\
\text { Islam }\end{array}$ & 8,60 & 8,00 & 8,00 \\
\hline \multirow{2}{*}{$\begin{array}{l}\text { QuickAccess } \\
1 \text { Profil } \\
\text { Raport Siswa }\end{array}$} & SMT $2 /$ GENAP & 2. & Bahass Indonesia & 9,00 & 8,60 & 8,00 \\
\hline & SMT 3/GASAL & 3. & Pkn & 8,00 & - & 8,00 \\
\hline \multirow{2}{*}{$\begin{array}{l}\text { Cerkembangan Studi } \\
\text { S Tagihan SPP }\end{array}$} & SMT 4/GENAP & 4. & Matematika & 8,50 & - & 8,00 \\
\hline & & 5. & $\begin{array}{l}\text { Ilmu Pengetahuan } \\
\text { Alam }\end{array}$ & 9,20 & 8,60 & 8,00 \\
\hline \multirow{2}{*}{$\begin{array}{l}\text { Agenda } \\
=\text { Cetak } \\
{ }_{\text {Pesan }}\end{array}$} & & 6. & $\begin{array}{l}\text { IImu pengetahuan } \\
\text { Sosial } \\
\end{array}$ & 8,00 & 8,00 & 8,00 \\
\hline & & 7. & Bahasa Ingeris & 8,00 & 8,00 & 8,00 \\
\hline
\end{tabular}

Gambar 16 Raport Siswa dalam Tampilan Siswa 
Al-Ishlah: Jurnal Pendidikan - ISSN: 2087-949o (p); 2597-940X (e)

Vol. 12, No. 1 (2020)

Jika memilih ikon raport siswa maka akan muncul menu Pilih Semester yang berfungsi untuk melihat nilai sesuai dengan semester yang dipilih. Pada raport online ini tampilannya sama seperti raport cetak pada umumnya hanya berbeda pada bentuk fisiknya saja.

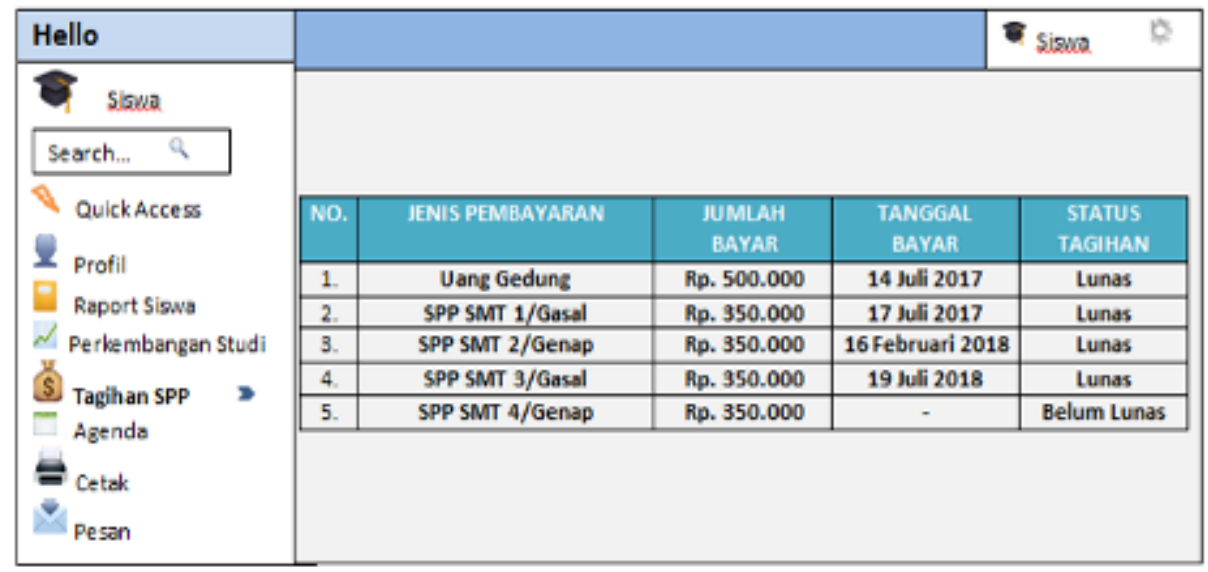

Gambar 17 Tagihan SPP dalam Tampilan Siswa

Jika memilih ikon tagihan SPP maka akan muncul kolom yang berisi jenis pembayaran, jumlah tagihan, tanggal bayar dan status tagihan. Setiap wali murid akan mendapat notifikasi jika sudah memasuki tanggal tagihan yang akan masuk pada ikon pesan. Untuk sistem pembayaran nantinya dapat dikirim melalui aplikasi pembayaran digital ataupun bank mitra lainnya.

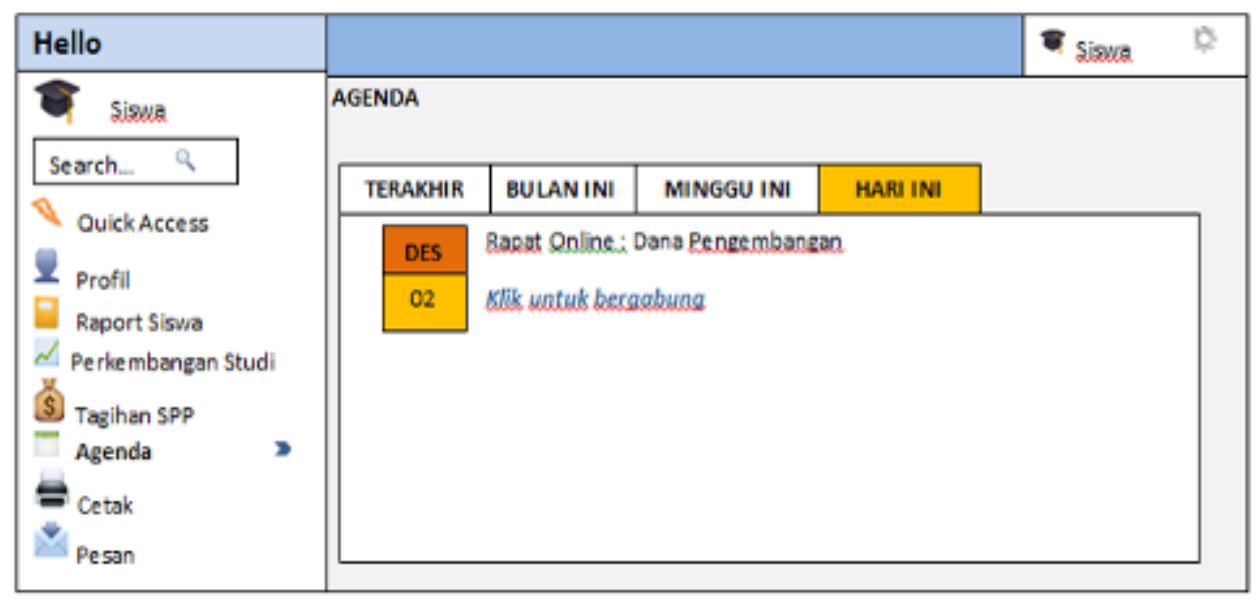

Gambar 18 Agenda dalam Tampilan Siswa 
Al-Ishlah: Jurnal Pendidikan - ISSN: 2087-9490 (p); 2597-940X (e)

Vol. 12, No. 1 (2020)

Pada ikon agenda berisi mengenai beberapa agenda yang akan dilaksanakan salah satunya rapat online. Agenda rapat online sendiri akan muncul notifikasi pada agenda Hari Ini yang berisi atau memuat tanggal pelaksanaan, tema yang akan dibahas serta link untuk bergabung.

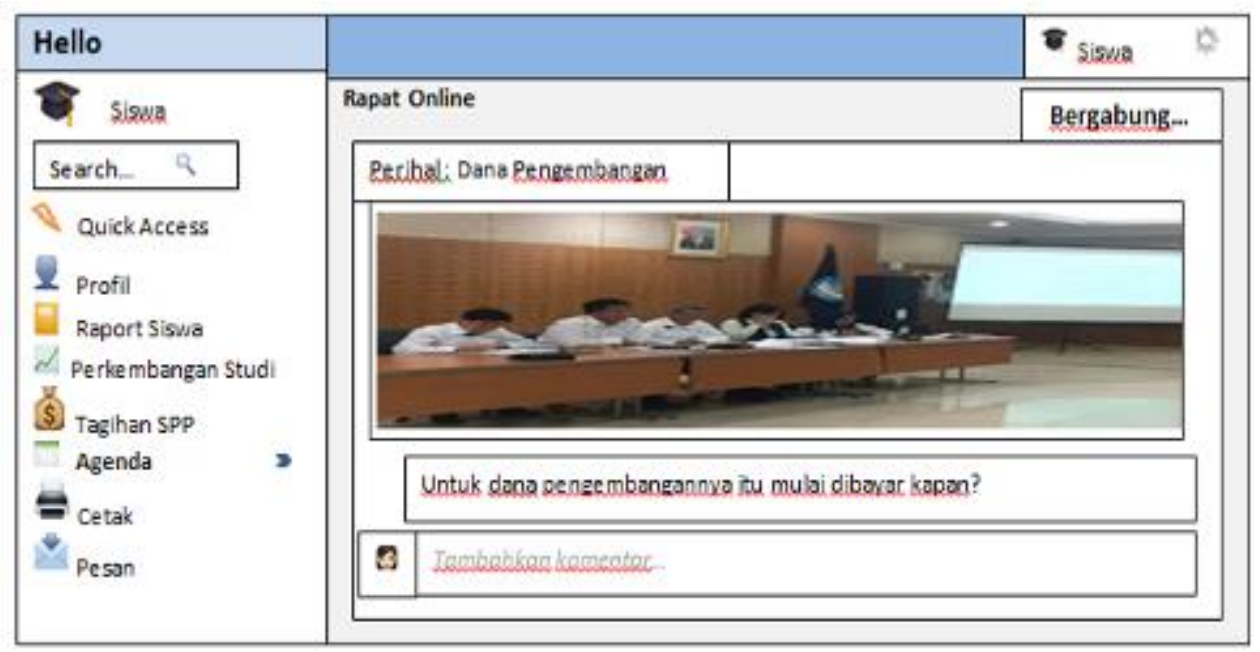

Gambar 19 Rapat Online dalam Fitur Agenda

Dalam fitur agenda, terdapat beberapa komponen diantaranya.

a) Judul rapat online, berisi agenda yang akan dibahas bersama.

b) Forum diskusi, berisi tayang live streaming rapat dan pertanyaan yang diajukan.

c) Kolom komentar, berisi pengajuan pertanyaan yang akan diterima atau ditanggapi oleh admin atau pihak sekolah.

Rancangan aplikasi ini berusaha untuk mengurangi penggunaan kertas (paper less) dalam sistem administrasi di sekolah baik raport, sistem pembayaran dan pengumuman sekolah yang biasanya berbentuk edaran kertas. Dalam rancangan aplikasi ini berisi sistem administrasi yang dapat diakses oleh orang tua siswa dimanapun dan kapanpun yang berbasis web. Sistem pengelolaan administrasi dokumen berbasis teknologi informasi melalui jaringan internet disebut E-administration (Masluroh, 2013).

Dalam aplikasi "Hello Parents" tampilan awal akan muncul menu login untuk admin atau tata usaha, guru atau wali kelas dan wali murid serta siswa yang akan mengakses aplikasi ini. Dalam tampilan login awal admin, wali kelas maupun wali murid harus memasukkan username dan password yang telah ditentukan. Username dan password untuk admin dibuat khusus yang hanya diketahui oleh pihak sekolah. Sedangkan untuk guru menggunakan nama guru sebagai username dan password dapat menggunakan nomor induk pegawai (NIP) 
Al-Ishlah: Jurnal Pendidikan - ISSN: 2087-949o (p); 2597-940X (e)

Vol. 12, No. 1 (2020)

atau dapat diganti oleh guru sendiri. Selanjutnya username dan password siswa menggunakan nama lengkap siswa dan nomor induk siswa (NIS) .

Dalam tampilan menu admin akan muncul beberapa fitur yang terdapat dalam aplikasi ini. Beberapa fitur tersebut merupakan fitur informasi sekolah secara lengkap. Dalam tampilan ini admin bisa merubah informasi-informasi mengenai sekolah. Kemudian untuk guru, setelah login akan muncul tampilan lengkap mengenai data siswa dalam kelas yang diampu guru tersebut. Dalam aplikasi ini, guru berperan ikut serta dalam mengelola aplikasi, serta melakukan edit data, seperti: biodata diri, input nilai, edit nilai siswa dan dapat membuka ruang diskusi atau konsultasi dengan wali murid mengenai perkembangan siswa.

Untuk wali murid, setelah login akan muncul tampilan lengkap mengenai data siswa yang sesuai dengan nama dan NIS yang dimasukkan. Wali murid dapat mengakses raport, perkembangan akademik, tagihan Sumbangan Pembinaan Pendidikan (SPP) serta diskusi ataupun rapat secara online.

Kekurangan atau kelemahan pada aplikasi Hello Parents ini yakni harus terhubung pada internet sehingga daerah yang terbatas sinyal internet tidak dapat menggunakan karena tidak dapat bersifat offline atau luar jaringan. Selain itu, kekurangan yang dihadapi yakni jika wali murid kesulitan beradaptasi dengan perkembangan teknologi (gaptek) akan mengalihkan penggunaan aplikasi ini kepada anak padahal aplikasi ini ditujukan kepada wali murid agar dapat berkomunikasi dengan wali kelas. Solusi yang ditawarkan untuk permasalahan pengalihan penggunaan yakni dengan mengadakan sosialisasi kepada wali murid.

\section{SIMPULAN}

Sistem dalam aplikasi "Hello Parents" dikelola oleh Tata Usaha (TU) sekolah yang berperan sebagai admin untuk mengelola, memperbaharui dan melakukan pemeliharaan aplikasi. Dalam penyusunan rancangan aplikasi ini menggunakan pengembangan model waterfall. Pemodelan waterfall merupakan metode pengembangan sistem yang sering digunakan oleh para pengembang sistem dengan tahap pengembangan sistem yang terstruktur (Harjanto, 2018). Rancangan aplikasi ini dapat mengoptimalkan kinerja guru sehingga dapat mengerjakan tugas pokok yang lain, seperti mendalami materi, menyusun silabus dan Rancangan Pelaksanaan Pembelajaran (RPP). Dapat menyusun laporan nilai siswa secara optimal. Kinerja guru dapat berjalan secara efektif dan efisien. Dari segi wali murid memudahkan dalam melihat perkembangan akademik siswa serta hasil belajar siswa, sehingga wali murid tidak harus datang ke sekolah untuk mengambil raport dan dapat mengefisiensi waktu. 
Al-Ishlah: Jurnal Pendidikan - ISSN: 2087-9490 (p); 2597-940X (e)

Vol. 12, No. 1 (2020)

Secara keseluruhan rancangan aplikasi ini memiliki manfaat yang berusaha mengurangi penggunaan kertas atau paper less, sehingga sekolah atau guru tidak perlu membuka buku besar. Rancangan "Hello Parents" ini berbentuk web sehingga data penting yang di input lebih aman dan memudahkan dalam pencarian data. Fitur utama yang terdapat aplikasi "Hello Parents" adalah raport online, perkembangan akademik, rapat online, dan tagihan atau pembayaran Sumbangan Pembinaan Pendidikan (SPP). Semua fitur-fitur tersebut disusun secara sederhana sehingga memudahkan pengguna dalam pengoperasian aplikasi ini.

\section{DAFTAR PUSTAKA}

Anam, Khaerul dan Asep Taufik Muharram. (2018). "Analisa dan Perancangan Sistem Informasi Akademik Berbasis Web Pada Mi Al-Mursyidiyyah AlAsyirotussyafi'iyyah". Jurnal Teknik Informatika. 11(2): 207-218.

Anwas, Oos M. (2011). "Pembudayaan Teknologi Informasi Dan Komunikasi Di Sekolah". Jurnal Teknodik. 15(1): 75-83.

Aristoteles, Aristoteles., et al. (2013). "Analisis dan Pengembangan Sistem Informasi Rapor Online Berbasis Web dan Mobile Pada SMA Negeri 1 Gedong Tataan”. Jurnal Komputasi. 1(1): 67-90.

Budiyarto, Nyuda Resio., dan Naim Rochmawati. (2016). "Sistem Informasi Raport Online SMA Negeri 1 Krembung”. Jurnal Manajemen Informatika. 6(1): 108-116.

Durachman, Yusuf. (2009). "Pengembangan Sistem Informasi Akademik Berbasis Web (Studi Kasus: SMA Muhammadiyah 7 Sawangan Depok)". Studia Informatika: Jurnal Sistem Informasi. 2(1): 51-56.

Erinawati, Heni Dwi. (2012). "Pembangunan Sistem Informasi Pembayaran Sekolah Pada Sekolah Menengah Atas (SMA) Negeri 1 Rembang Berbasis Web". Journal Speed - Sentra Penelitian Engineering dan Edukasi. 4(4): 40-46.

Harjanto, Arif., Sri Karnila, dan Fajar Nugraha. (2018). "Rancang Bangun Aplikasi Sistem Pakar Untuk Konsultasi Perilaku Siswa di Sekolah Menggunakan Metode Forward Chaining”. Jurnal Simetris. 9(2): 817-824.

Huda, Miftakhul. (2018). "Blended Learning: Improvisasi dalam Pembelajaran Menulis Pengalaman”. Lensa: Kajian Kebahasaan, Kesusastraan, dan Budaya. 8(2): 117-130. https://doi.org/10.26714/lensa.8.2.2018.117-130 
Al-Ishlah: Jurnal Pendidikan - ISSN: 2087-9490 (p); 2597-940X (e)

Vol. 12, No. 1 (2020)

Hussein, A., \& Mohammed, H. (2019). "Social-media based assessment of academic programs". Studies in Educational Evaluation. 62. 149-157. https://doi.org/10.1016/j.stueduc.2019.06.003

Lindasari, Emi, et al. (2017). "Manajemen Parenting Dalam Meningkatkan Hubungan Sekolah Dengan Orangtua".Manajemen dan Supervisi Pendidikan. 1(2) : 146-155.

Masluroh, Haniatun. (2013).”Sistem Online Administrasi Kurikulum Sebagai Solusi Perbaikan Layanan Administrasi Di Sma Nahdlatul Ulama 1 Gresik" Didaktika. 19(2): 1-10.

Membara, Eko Putra, et al. (2014). "Sistem Informasi Akademik SMP Negeri 2 Talang Empat Berbasis Web". Jurnal Media Infotama. 10(1): 72-80.

Nandika, Galuh Raga., et al. (2014). "Pengembangan Aplikasi Pengolahan Nilai Siswa Berbasis Web Di Sekolah Dasar Negeri Sukagalih V”. Sttgarut. 11(1): 1-8.

Pangastuti, Putu Ayu Desy, et al. (2019). "Penerapan Sistem Informasi Raport Online". Ekuitas: Jurnal Pendidikan Ekonomi. 7(1): 1-4.

Prasetya, Roliand., Fajar Pradana, dan Achmad Arwan. (2018). "Pengembangan Aplikasi Manajemen Notula Rapat Menggunakan Google Speech API Berbasis Android". Jurnal Pengembangan Teknologi Informasi dan Ilmu Komputer. 2(10): 4171-4178.

Rochman, Abdur., Achmad Sidik, dan Nada Nazahah. (2018). "Perancangan Sistem Informasi Administrasi Pembayaran SPP Siswa Berbasis Web di SMK Al-Amanah”. Jurnal Sisfotek Global. 8(1): 51-56.

Saputra, Putu Satya., et al. (2017). "Sistem Informasi Monitoring Perkembangan Anak di Sekolah Taman Kanak-kanak Berbasis Cluod". Lontar Komputer. 8(2): 112-123.

Suryandani, Farid., Basori, dan Dwi Maryono. (2017). "Pengembangan Sistem Informasi Akademik Berbasis Web Sebagai Sistem Pengolahan Nilai Siswa di SMK Negeri 1 Kudus". Jurnal Ilmiah Pendidikan Teknik Kejuruan. 10(1): 71-82.

Susanti, Melan .(2016). "Perancangan Sistem Informasi Akademik Berbasis Web Pada SMK Pasar Minggu Jakarta”. Jurnal Informatika. 3(1):91-99.

Syahbana, Ali. (2013). "Pembangunan Sistem Informasi Administrasi Pembayaran Siswa Madrasah Aliyah Ma'arif Pacitan”. Journal Speed - 
Al-Ishlah: Jurnal Pendidikan - ISSN: 2087-949o (p); 2597-940X (e)

Vol. 12, No. 1 (2020)

Sentra Penelitian Engineering dan Edukasi Journal Speed - Sentra Penelitian Engineering dan Edukasi. 5(3): 63-68.

Wardani, Susy Kusuma .(2013). "Sistem Informasi Pengolahan Data Nilai Siswa Berbasis Web Pada Sekolah Menengah Atas (SMA) Muhammadiyah Pacitan". IJNS- Indonesian Journal on Networking and Security. 2(2):3037.

Yamalia, Ikke., dan Saut Siagian. (2019). "Analisa Sistem Informasi Pengolahan Data Nilai Siswa Berbasis Web”. Journal V-Tech (Vision Technology). 2(1): 75-80.

Yusuf, Yuda Pramudhya., et al. (2017). "Implementasi Sistem Informasi Sekolah berbasis WEB untuk Komunikasi Antara Guru dan Orang Tua Murid di SDN Kamasan 4 Banjaran”. e-Proceeding of Applied Science. 3(2): 675683. 